\title{
Do we really know the duration of pain after rib fracture?
}

\author{
Cumhur Murat Tulay ${ }^{1}$, Sadik Yaldiz ${ }^{1}$, Adnan Bilge ${ }^{2}$ \\ ${ }^{1}$ Thoracic Surgery Department, School of Medicine, Manisa Celal Bayar University, Manisa, Turkey \\ ${ }^{2}$ Emergency Department, School of Medicine, Manisa Celal Bayar University, Manisa, Turkey
}

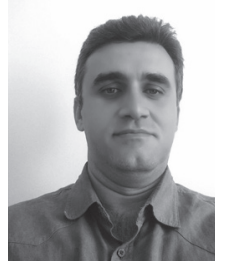

Kardiochirugia i Torakochirugia Polska 2018; 15 (3): 147-150

\begin{abstract}
Introduction: The duration of pain after rib fracture is the question physicians are most frequently asked. The duration of pain following a traumatic rib fracture without any comorbidity is not widely published.

Aim: We report our experience to investigate the duration of pain following isolated traumatic rib fractures without any traumatic comorbidity.

Material and methods: We examined 182 patients with isolated rib fracture without any trauma to other body parts. The numeric rating scale (NRS) for pain was used to rate the level of pain. The NRS pain scores were evaluated in the emergency department at presentation, on the $15^{\text {th }}$ day, and at the $3^{\text {rd }}$ and $6^{\text {th }}$ months of trauma. The Mann-Whitney $U$ test was performed for the statistical analysis.

Results: The pain level of young patients on the $15^{\text {th }}$ day and at the third month and sixth month was lower than that in the old group, and the difference was statistically significant. While patients with two rib fractures had a higher pain level in the emergency room than those with one rib fracture, there was no statistically significant difference at other time points. In patients with anterior fractures, the pain level was significantly lower than in the lateral and posterior regions, whereas in the lateral fractures, the pain score was significantly higher than others at all time points except at the $6^{\text {th }}$ month. The pain score of displaced fractures was significantly higher than that of non-displaced ones at all time points except the 6-month follow-up.

Conclusions: Rib fractures cause significant pain and need appropriate medication. The time of the $6^{\text {th }}$ month could be an important milestone.
\end{abstract}

Key words: rib fracture, chest trauma, pain, chest pain.

\section{Streszczenie}

Wstęp: Lekarze są najczęściej pytani o to, jak długo utrzymuje się ból po złamaniu żeber. Zagadnienie czasu trwania bólu po urazowym złamaniu żeber bez innych schorzeń wspótistniejących nie jest często podejmowane w piśmiennictwie.

Cel: Niniejsza praca stanowi próbę określenia czasu utrzymywania się dolegliwości bólowych po urazowym złamaniu żeber bez innych współistniejących schorzeń urazowych na podstawie doświadczeń własnych.

Materiały i metody: Zbadano 182 pacjentów ze złamaniem żeber bez towarzyszących urazów innych części ciała. Do oceny poziomu bólu wykorzystano skalę numeryczną (NRS). Stopień bólu oceniano w izbie przyjęć podczas przyjęcia, a następnie w 15. dniu oraz w 3. i 6. miesiącu po urazie. W analizie statystycznej wykorzystano test $U$ Manna-Whitneya.

Wyniki: Poziom bólu u młodszych pacjentów w 15. dniu, a także w 3. i 6. miesiącu był niższy niż u osób starszych, a różnica ta była istotna statystycznie. Pacjenci, u których wystąpiło złamanie dwóch żeber, zgłaszali wyższy poziom bólu w izbie przyjęć niż pacjenci ze złamanym jednym żebrem, jednak w pozostałych okresach pomiaru nie stwierdzono statystycznie istotnej różnicy. Pacjenci ze złamaniami przednich części zgłaszali niższy poziom bólu niż pacjenci ze złamaniami tylnych lub bocznych części. W przypadku złamań części bocznych poziom bólu był znacząco wyższy we wszystkich okresach pomiaru poza 6. miesiącem. Poziom bólu w przypadku złamań z przemieszczeniem był znacząco wyższy niż w przypadku złamań bez przemieszczenia podczas wszystkich pomiarów poza wizytą kontrolną w 6. miesiącu.

Wnioski: Złamania żeber są źródłem znaczącego bólu i wymagają stosowania odpowiednich leków. Szósty miesiąc może mieć ważne znaczenie.

Słowa kluczowe: złamanie żeber, uraz klatki piersiowej, ból, ból w klatce piersiowej.

Address for correspondence: Cumhur Murat Tulay MD, Thoracic Surgery Department, School of Medicine, Manisa Celal Bayar University, 45030 Manisa, Turkey, phone: +90 2362360330, e-mail: cumhurtulay@hotmail.com

Received: 11.05.2018, accepted: 3.06.2018. 


\section{Introduction}

The incidence of chest trauma represents $10-15 \%$ of all traumas, of which $85 \%$ of patients have rib fractures. Rib fractures usually cause severe chest pain, difficulty in breathing and cough, and a change in the body posture could decrease the pain intensity $[1,2]$.

Blunt thoracic trauma is a common cause of rib fractures, and traumatic rib fractures are one of the leading causes of morbidity and mortality. Only a few studies have assessed the duration of pain after rib fractures and related disability [3-5].

The duration of pain following a traumatic rib fracture is not widely published. The duration of pain after rib fracture is the most common question physicians are asked in daily clinical practice.

\section{Aim}

In this study, we report our experience to investigate the duration of pain following isolated traumatic rib fractures without any traumatic comorbidity.

\section{Material and methods}

We examined 182 consecutive patients prospectively with an isolated rib fracture who were admitted to our emergency department between January 2016 and December 2016 without any trauma to other body parts. Chest $X$-ray and computed tomography were performed on all patients. Patients who had one or two isolated rib fractures without multiple traumas were enrolled in this study. Physical and radiological examination proved rib fractures in patients. We divided the hemithorax into the following three regions: (a) anterior region, between the sternum and the anterior axillary line; (b) lateral region, between the anterior and posterior axillary lines; and (c) posterior region, between the posterior axillary line and the vertebrae. The numeric rating scale for pain (NRS Pain) was used to rate patients' level of pain. We did not hospitalize any patient because no additional pathology was observed. Informed consent was taken from all patients We prescribed $250 \mathrm{mg}$ paracetamol/150 mg propyphenazone/50 mg caffeine combination + $200 \mathrm{mg}$ phenprobamate/200 mg paracetamol combination + local nonsteroidal anti-inflammatory drug (NSAID) to be taken twice a day. All patients were advised

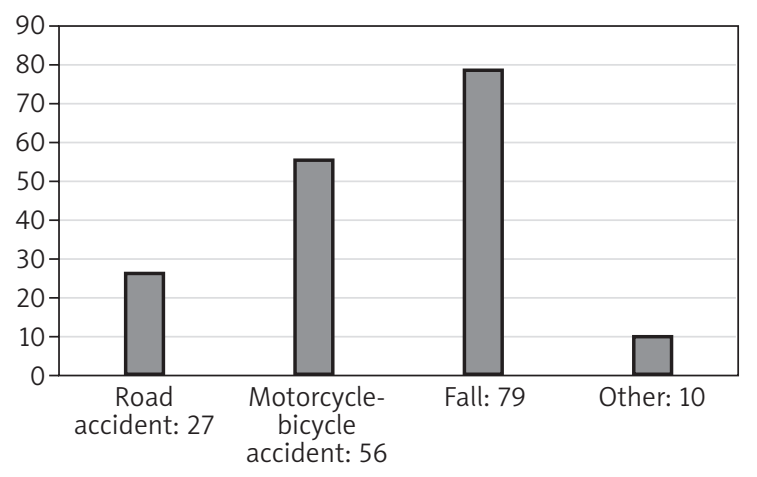

Figure 1. Mechanism of rib fractures on deep breathing, the three-ball spirometer, coughing, mobilization and sleeping in the supine position at $45-60^{\circ}$. Patients underwent regular treatment for 1 month. At follow-up, we wanted patients to bring their prescribed pain medications and asked whether they used their medication regularly or not.

The inclusion criteria for the study were thoracic trauma that caused only rib fracture without comorbidities (head, extremity, lung and abdominal trauma), admission to our hospital on the day of trauma and no admission to any other hospital without taking any pain medication.

The exclusion criteria were multiple trauma to other body regions, pleural or lung parenchymal injury (e.g. pneumothorax, hemothorax, contusion and traumatic lung cysts), flail chest, bilateral rib fractures, operative rib fixation, chronic drug usage and comorbidities (diabetes mellitus and malignancies) and age less than 18 years.

Two weeks after trauma, we analyzed all patients' chest X-ray to observe any pleural or lung parenchymal pathology. The NRS for pain was used to understand the effectiveness of the medical therapy. The NRS pain scores were evaluated in the emergency department at presentation $\left(p^{1}\right)$, on the $15^{\text {th }}$ day of trauma with a chest X-ray for a thoracic surgery outpatient clinic $\left(p^{2}\right)$ and at the third $\left(p^{3}\right)$ and sixth months of trauma $\left(p^{4}\right)$ with a telephone call. We asked patients the following two questions by telephone: (1) Do you have pain related to trauma? If yes, what is your pain score from '0' to '10'? (2) Do you need regular pain medication? We used a pain questionnaire using the NRS Pain ranging from 0 (no pain at all) to 10 (worst possible pain). If a patient did not have any pain at the site of thoracic injury, no further questions were asked. When a patient complained of the presence of pain, the second question was asked.

\section{Statistical analysis}

The Mann-Whitney $U$ test was performed for the statistical analysis, and $p \leq 0.05$ was considered statistically significant.

\section{Results}

We examined 182 thoracic trauma patients and excluded 10 of them because of documented serious osteoporosis, chronic drug usage for rheumatologic disorders and malignancy. In this study, we enrolled 172 (66 females and 106 males) patients with one or two rib fractures. The causes of rib fracture are shown in Figure 1. The median age of patients was 47 years (minimum: 18 years; maximum: 85 years). We identified patients who were 65 years or older as 'old' and less than 65 years as 'young'. Of these, 144 patients were young and 28 were old. We determined one rib fracture in 98 patients and two rib fractures in 74 patients. Eighty-two patients had a fracture on the right hemithorax, and 90 had one on the left hemithorax. The anterior part of rib fractures was identified in 60 , lateral in 52 and posterior in 60 patients. Simple (non-displaced) fractures appeared as cracks on the ribs or a jagged edge. The displaced fractures lacked a contour along 
Table I. Characteristics and pain level of patients during the study period $(N=172)$

\begin{tabular}{|c|c|c|c|c|c|}
\hline \multirow[t]{3}{*}{ Parameter } & \multicolumn{4}{|c|}{ Pain level } & \multirow[t]{3}{*}{$P$-value } \\
\hline & Presentation & $15^{\text {th }}$ day & $3^{\text {rd }}$ month & $6^{\text {th }}$ month & \\
\hline & $\begin{array}{c}\text { Median } \\
\left(25^{\text {th }}-75^{\text {th }} \%\right)\end{array}$ & $\begin{array}{c}\text { Median } \\
\left(25^{\text {th }}-75^{\text {th }} \%\right)\end{array}$ & $\begin{array}{c}\text { Median } \\
\left(25^{\text {th }}-75^{\text {th }} \%\right)\end{array}$ & $\begin{array}{c}\text { Median } \\
\left(25^{\text {th }}-75^{\text {th }} \%\right)\end{array}$ & \\
\hline Young patients $(n=144)$ & $9(8-10)$ & $2(2-3)$ & $1(0-2)$ & $0(0-1)$ & \multirow{2}{*}{$\begin{array}{l}p^{2}=0.012 \\
p^{3}=0.001 \\
p^{4}=0.002\end{array}$} \\
\hline Old patients $(n=28)$ & $10(10-10)$ & $4(3-4)$ & $2(2-3)$ & $1(1-1)$ & \\
\hline Female $(n=66)$ & $10(9-10)$ & $3(2-4)$ & $2(1-2)$ & $1(0-1)$ & \multirow{2}{*}{$\begin{array}{l}p^{2}=0.006 \\
p^{3}=0.002 \\
p^{4}=0.002\end{array}$} \\
\hline Male $(n=106)$ & $9(8-10)$ & $2(2-3)$ & $1(0-1)$ & $0(1-0)$ & \\
\hline 1 fracture $(n=98)$ & $9(8-10)$ & $2(2-4)$ & $1(0-2)$ & $0(0-1)$ & \multirow[t]{2}{*}{$p^{1}=0.032$} \\
\hline 2 fractures $(n=74)$ & $10(9-10)$ & $3(2-3)$ & $1(1-2)$ & $0(0-1)$ & \\
\hline Right side fracture $(n=82)$ & $10(9-10)$ & $2(2-4)$ & $1(1-2)$ & $0(0-1)$ & \multirow[t]{2}{*}{$p^{1}=0.043$} \\
\hline Left side fracture $(n=90)$ & $9(8-10)$ & $3(2-3)$ & $1(0-2)$ & $0(0-1)$ & \\
\hline Anterior $(n=60)$ & $8(8-9)$ & $2(2-3)$ & $0(0-1)$ & $0(0-0)$ & \multirow{3}{*}{$\begin{array}{l}p^{1}=0.001 \\
p^{2}=0.009 \\
p^{3}=0.001\end{array}$} \\
\hline Lateral $(n=52)$ & $10(9-10)$ & $3(2.5-4)$ & $2(1-2)$ & $1(0-1)$ & \\
\hline Posterior $(n=60)$ & $10(9-10)$ & $3(2-3)$ & $1(1-1)$ & $0(0-0.5)$ & \\
\hline Displaced $(n=98)$ & $10(9-10)$ & $3(2-4)$ & $1(1-2)$ & $0(0-1)$ & \multirow{2}{*}{$\begin{array}{l}p^{1}=0.001 \\
p^{2}=0.006 \\
p^{3}=0.038\end{array}$} \\
\hline Non-displaced $(n=74)$ & $9(8-9)$ & $2(2-3)$ & $1(0-2)$ & $0(0-1)$ & \\
\hline
\end{tabular}

the edge of the rib on the X-ray. Ninety-eight patients had a displaced rib fracture, whereas 74 had a non-displaced rib fracture.

At presentation, the pain levels of young and old patients were $9.07 \pm 0.94$ and $9.43 \pm 0.85$, respectively. Although no difference was observed in the pain level in the emergency department at presentation $\left(p^{1}=0.157\right)$, the pain level of young patients on the $15^{\text {th }}$ day, and at the third month and sixth month, was lower than that in the old group, and the difference was statistically significant $\left(p^{2}=0.012 ; p^{3}=0.001 ; p^{4}=0.002\right.$, respectively) (Table I).

Although the pain level of female patients was slightly higher than that of male patients at presentation, the difference was not significant $\left(p^{1}=0.189\right)$. The pain level of female patients was significantly higher on the $15^{\text {th }}$ day and at the third month and sixth month $\left(p^{2}=0.006\right.$; $p^{3}=0.002$ and $p^{4}=0.002$, respectively).

While patients with two rib fractures had a higher pain level at presentation than those with one rib fracture $\left(p^{1}=0.032\right)$, there was no statistically significant difference on the $15^{\text {th }}$ day and at the third month and sixth month $\left(p^{2}=0.993 ; p^{3}=0.534 ; p^{4}=0.794\right.$, respectively).

Furthermore, no statistically significant difference was observed in the laterality and pain level of the rib fracture at follow-up periods, except at presentation. Patients with fractures on the right side complained more about pain than those with fractures on the left side $\left(p^{1}=0.043\right)$.

In patients with anterior fractures, the pain level was significantly lower at presentation, the $15^{\text {th }}$ day and third month than in the lateral and posterior regions, whereas in the lateral fractures, the pain score was significantly higher than in the other region fractures at all time points except the $6^{\text {th }}$ month $\left(p^{1}=0.001, p^{2}=0.009, p^{3}=0.001\right)$.
The pain score of the displaced fractures was significantly higher than the non-displaced ones at all time points except the 6-month follow-up $\left(p^{1}=0.001 ; p^{2}=0.006\right.$; $p^{3}=0.038$ and $\left.p^{4}=0.551\right)$.

No patient in this study used regular medication for pain after 1 month. At the sixth month, only 11 patients said, "I have mild pain in cold weather and while lifting heavy objects. I do not need to take pain medication. The pain subsides after resting."

\section{Discussion}

Rib fractures cause pain and interfere with the quality of life, particularly in the early post-injury period $[3,5,6]$. The rib fracture pain originates at the site of the fractured bone and injured muscle and sometimes radiates to the back, especially to the dermatomal area. This pain is usually reported by patients to be exacerbated by any movement of the chest wall (e.g. with respiration and most certainly with deep breathing and coughing) [7].

The current therapy for rib fractures at most of the centers consists of intravenous opioids and/or an epidural catheter for analgesia [3]. To apply these treatment modalities, patients have to be admitted to a hospital. Previous research usually studied patients who had multi-trauma, rib fractures with comorbidities and mostly those who were hospitalized. A majority of patients who were included in these studies had other concomitant injuries to other body parts $[3-5,8,9]$.

Our study is different in that regard as it only consists of patients with one or two isolated rib fractures without any other trauma or comorbidities and hospitalization. Patients who have more than two rib fractures should be hospitalized. We aimed to follow up patient at an outpatient clinic 
with pain medications without hospitalization. None of the patients in our study were hospitalized, and all of them were followed up at an outpatient clinic with a prescribed pain management protocol. Our results provide specific pain duration after one or two isolated rib fractures.

In our study, we selected a homogeneous group of patients with one or two rib fractures without any concomitant injury. Hence, we solely tried to reveal the duration of pain after a rib fracture. Pain is a subjective sensation, and an objective measurement of pain levels is challenging. We wanted to observe and evaluate the rib fracture pain without pain in any other part of the body. We believe that pain in any other part of the body could affect the body posture and could be confused with the rib fracture pain. In our literature review, we could not find any information about the duration of pain management with drug regimens for an outpatient clinic. We hope that our results will guide clinicians about rib fractures.

There is no absolute time to heal after rib fracture. We emphasize that healing and pain perception are different entities. They could be related to each other, or the healing process could be longer than expected and the time of pain perception could depend on feeding status, life-style of patients, and body mass index. It is very difficult to optimize and provide a standard life style for all patients. In the literature, there is a broad range of pain duration from 8 weeks to 24 months after a rib fracture $[3,4,6,9]$.

It was mostly found that no correlation existed between the number of rib fractures and the level of pain [4, 9]. Although not statistically significant, Kerr-Valentic demonstrated a modest correlation [3]. We found that the pain level of patients with two rib fractures was greater than that for one fracture on the day of trauma; however, no statistically significant difference was found at other times.

We found that lateral region fractures caused more pain than anterior and posterior rib fractures. It is thought that the lateral chest wall rib fracture is the most affected part of respiration and body movement.

Rib fractures caused by minimal trauma are one of the most common fractures among the elderly. Although the impact of age on morbidity and mortality with traumatic rib fractures has been well described, rib pain relief with time is not well documented in the English literature. In our study the pain level of elderly patients on the $15^{\text {th }}$ day and at the third month and sixth months was greater than that in the young group, and the difference was statistically significant. We believe that there may be an association between bone mineral density and rib fracture healing.

No clear guidelines exist to manage outpatient care for post-traumatic analgesia prescription. Inadequate acute pain management may cause prolonged and chronic pain. Acute phase control of rib fracture pain could affect the chronic pain $[4,6]$. Over the past two decades, researchers have discovered that the persistence of severe, inadequately treated pain could lead to anatomic and physiologic changes in the nervous system. The ability of the neural tissue to change in response to repeated incoming stimuli, a property known as neuroplasticity, can lead to the development of chronic, disabling neuropathic pain when acute pain is poorly treated [10]. We preferred a paracetamolbased combination treatment for rib fracture pain, because it has fewer gastrointestinal side effects and is cheaper than NSAID. Although there was a decrease in pain level at the $15^{\text {th }}$ day of trauma, the pain persisted. For this reason, all patients used our treatment protocol for 1 month regularly. In our study, our pain management protocol was very effective according to the pain scores. It may be suggested that the combination treatment modalities are valuable for pain management to control acute pain.

\section{Limitations}

We did not evaluate the time of return to work, and this might be important for the insurance status. In addition, the effect of nutritional status on pain relief such as height, weight and body mass could have been investigated and analyzed.

\section{Conclusions}

Rib fractures cause significant pain and need appropriate medication. The pain perception period may be longer for older and female patients. The time of the $6^{\text {th }}$ month could be an important milestone. Chronic pain can be prevented with regular combination drug treatment.

\section{Disclosure}

The authors report no conflict of interest.

\section{References}

1. Wu WM, Yang Y, Gao ZL, Zhao TC, He WW. Which is better to multiple rib fractures, surgical treatment or conservative treatment? Int I Clin Exp Med 2015; 8: 7930-7936.

2. Altunkaya A, Aktunc E, Kutluk AC, Buyukates M, Demircan N, Demir AS. Analysis of 282 patients with thoracic trauma. Turk J Thorac Cardiovasc Surg 2007; 15: 127-132.

3. Kerr-Valentic MA, Arthur M, Mullins RJ, Pearson TE, Mayberry JC. Rib fracture pain and disability: can we do better? J Trauma 2003; 54: 1058-1063.

4. Shelat VG, Eileen S, John L, Teo LT, Vijayan A, Chiu MT. Chronic pain and its impact on quality of life following a traumatic rib fracture. Eur J Trauma Emerg Surg 2012; 38: 451-455.

5. Fabricant L, Ham B, Mullins R, Mayberry J. Prolonged pain and disability are common after rib fractures. Am J Surg 2013; 205: 511-515.

6. Marasco S, Lee G, Summerhayes R, Fitzgerald M, Bailey M. Quality of life after major trauma with multiple rib fractures. Injury 2015; 46: 61-65.

7. Gabram SG, Schwartz RJ, Jacobs LM, Lawrence D, Murphy MA, Morrow JS, Hopkins JS, Knauft RF. Clinical management of blunt trauma patients with unilateral rib fractures: a randomized trial. World J Surg 1995; 19: 388-393.

8. Lin FC, Li RY, Tung YW, Jeng KC, Tsai SC. Morbidity, mortality, associated injuries, and management of traumatic rib fractures. J Chin Med Assoc 2016; 79: 329-334.

9. Gordy S, Fabricant L, Ham B, Mullins R, Mayberry J. The contribution of rib fractures to chronic pain and disability. Am J Surg 2014; 207: 659-662.

10. Woolf CJ, Salter MW. Neuronal plasticity: Increasing the gain in pain. Science 2000; 288: 1765-1769. 